УДК 657.01

DOI: https://doi.org/10.32782/2520-2200/2020-2-20

Соколенко Л.Ф. кандидат економічних наук, доцент кафедри бізнес-економіки та адміністрування

Сумського державного педагогічного університету імені А.С. Макаренка

Sokolenko Lyudmyla Sumy State Pedagogical University named after A.S. Makarenko

ОБ'ЄКТИ БУХГАЛТЕРСЬКОГО ОБЛІКУ ДІЯЛЬНОСТІ КЕРУЮЧИХ КОМПАНІЙ СФЕРИ ЖКГ: ТРАНСФОРМАЦІЯ ПІДХОДУ ДО ІДЕНТИФІКАЦІЇ

\title{
ACCOUNTING OBJECTS IN HOUSING AND UTILITY MANAGEMENT COMPANIES: TRANSFORMATION OF THE IDENTIFICATION APPROACH
}

У статті обгрунтовано доцільність підходу до ідентифікації об'єктів бухгалтерського обліку у керуючих компаніях сфери житлово-комунального господарства на основі визначення ії основних бізнес-процесів. Установлено структуру бізнес-процесів досліджених компаній, до яких належать підтримка функціонування матеріально-технічної бази та онлайн-платформи компанії, робота 3 постачальниками і підрядниками, робота зі споживачами (надання послуг та супровід фінансових операцій). Визначено, що впровадження поділу об'єктів бухгалтерського обліку за бізнес-процесами сприятиме зростанню ефективності використання ресурсів компанії, прозорості облікової інформації для ухвалення управлінських рішень, оперативному використанню інформації із 
загальнодержавних реєстрів відкритих даних, формуванню інформаційно-аналітичного базису управління бізнес-процесами керуючої компанії в єдиному інформаційному просторі.

Ключові слова: керуюча компанія у сфрері ЖКГ, об'єкти бухгалтерського обліку, житлово-комунальні послуги, бізнес-процеси, житлово-комунальна інфрраструктура, розрахунки з постачальниками і споживачами.

В статье обоснована целесообразность подхода к идентификации объектов бухгалтерского учета в управляющих компаниях сореры жилищно-коммунального хозяйства на основе определения ее основных бизнес-процессов. Установлена структура бизнес-процессов таких компаний, к которым относятся поддержка функционирования материально-технической базы и онлайнплатформы, работа с поставщиками и подрядчиками, работа с потребителями (предоставление услуг и сопровождение финансовых операций). Внедрение деления объектов бухгалтерского учета по бизнес-процессам будет способствовать росту эфрфективности использования ресурсов, прозрачности учетной информации для принятия управленческих решений, оперативному использованию информации из общегосударственных реестров открытых данных, фрормированию информационно-аналитического базиса управления бизнес-процессами управляющей компании в едином информационном пространстве.

Ключевые слова: управляющая компания в сорере ЖKX, объекты бухгалтерского учета, жилищно-коммунальные услуги, бизнес-процессы, жилищно-коммунальная инфраструктура, расчеты с поставщиками и потребителями.

Appropriate accounting of business operations of housing and utility management company requires the conceptual construction of the system of accounting objects, based on its business processes peculiarities. For the purpose of forming a system of accounting and informational support for business processes in such management company and their re-engineering we should take into account features of each business process. In addition, the same resources involved to different business processes are used with different levels of profitability. Understanding the activity of a management company through the structure of its business processes will transform the system of accounting objects by activity vectors and enabling to take into account the sectoral features of housing and utility. Therefore, the task of accounting organization is to ground the structure and levels of analytics that would allow to obtain information about the material and human resources and staff involved into business processes and sub-processes. Grounded that detailed nomenclature of the list of processes and operations will allow determining reserves of labor and resources productivity. Development of the analytical structure of accounts give the possibility to identify the individual volume of services consumption (with normal indicators of use, reduction or expansion of consumption). Established, that the structure of business processes of the housing and utility management company include support of the material and technical base and online platform functioning, relations with suppliers and contractors, relations with consumers (provision of services and support of financial transactions). It is determined that the division of accounting objects by business processes will increase the efficiency of company resources using. Moreover, it will increase the transparency of accounting information for making management decisions and disclosure if financial statements. Also it will allow to use information from national open data sources and form the informational and analytical basis of management in a single information space.

Key words: housing and utility management company, accounting objects, housing and communal services, business processes, housing and communal infrastructure, suppliers and consumers settlements.

Постановка проблеми. Сучасне розуміння «правильного» та клієнтоорієнтованого бізнесу все більш виходить за межі класичного розуміння сорери послуг, охоплюючи сферу житлово-комунального господарства (ЖКГ). Споживачі як основні стейкхолдери такої діяльності виставляють нові вимоги до якості обслуговування, оперативності розрахунків та прозорості їх фрормування. Натомість процеси цифровізації глобальної, а разом із ними і національної економіки трансорормують уявлення про механізми взаємодії керуючих компаній у сорері ЖКГ зі своїми клієнтами, а клієнтоорієнтований підхід визначає прагнення таких компаній змінити власні бізнес-моделі, адаптуючись до викликів конкурентних ринкових умов.
Належне облікове відображення господарських операцій керуючої компанії у сорері ЖКГ вимагає концептуальної побудови передусім системи об'єктів бухгалтерського обліку виходячи з особливостей її бізнес-процесів господарської діяльності. Структурне ускладнення підприємницьких структур та організаційноправових засад діяльності таких компаній визначає потребу дослідження трансформації бізнес-процесів, адже в “класичні» структури існуючі закономірності розвитку компаній уже не вписуються, що визначає актуальність представленого дослідження.

Аналіз останніх досліджень і публікацій. Теоретико-методологічні питання бізнес-процесів та управління ними активно вивчають В. Стадник 
та П. Іжевський [5], І.І. Стец [6], Л.І. Чернобай та О.І. Дума [8], Л.М. Таранюк [7]. Окремо слід виділити питання реінжинірингу бізнес-процесів, які досліджують О.М. Криворучко [2], О.В. Ольшанський [3; 4] та В.М. Ключарьов [4]. Разом із тим питання бізнес-процесів у контексті бухгалтерського обліку майже не розглядаються, тому слід звернути увагу на результати досліджень В.А. Дерія та М.В. Гуменної-Дерій [1].

Метою дослідження $€$ наукове обґрунтування підходу до ідентифікації об'єктів бухгалтерського обліку у керуючих компаніях сорери ЖКГ на основі визначення її основних бізнеспроцесів.

Виклад основного матеріалу дослідження. Управління бізнес-процесами для сучасних компаній усіх галузей національної економіки набуває вирішального значення в умовах посилення невизначеності та нестабільності ринкового середовища. Як відзначають О.В. Ольшанський та В.М. Ключарьов, «у сучасних умовах використання процесно-орієнтованої системи управління організацією дає змогу отримати відчутні переваги, оскільки система взаємопов'язаних і взаємодіючих бізнес-процесів має кінцеву мету - створення продуктів або послуг, які мають цінність як для зовнішніх, так і внутрішніх споживачів» [4]. Погоджуючись із даним твердженням, уважаємо, що такий самий підхід нині актуальний і для діяльності керуючих компаній у сорері ЖКГ, адже традиційно компанії цієї сорери сприймаються як «радянські жеки». Тому переосмислення бізнес-процесів цих компаній дасть змогу осучаснити їхню діяльність, підвищити рівень задоволеності споживачів, сприятиме модернізації системи ЖКГ на основі досягнення ефективності управління нею.

За словами В.А. Дерія та М.В. ГуменноїДерій, сучасний бізнес не може розвиватися без сегментації бізнес-процесів. "Це важливо з погляду мінімізації витрат на ці процеси і забезпечення максимізації доходів від них, тому керівник та менеджери підприємства мають постійно вдосконалювати класифрікацію бізнес-процесів, бо вона безпосередньо впливає його витрати і доходи, а також на конкурентоспроможність підприємства на ринку товарів (продукції, робіт, послуг)» [1]. Погоджуючись із такою позицією, зауважимо, що управління бізнес-процесами набуває комплексності та трансорормує концепції управління компаніями, орієнтуючи їх на цілісний розгляд проблем, урахування існуючих обмежень діяльності та вузьких місць.

Галузі ЖКГ притаманні власні риси, ризики та обмеження, тому формувати систему обліковоінформаційної підтримки бізнес-процесів керу- ючої компанії у сорері ЖКГ та їх реінжинірингу слід також у контексті рис таких бізнес-процесів, адже обмежуватися класичним поділом об'єктів бухгалтерського обліку вже складно.

Окрім того, одні й ті ж ресурси, долучені до різних бізнес-процесів, використовуються 3 різним рівнем рентабельності. Підхід до розуміння діяльності керуючої компанії крізь структуру її бізнес-процесів дасть змогу трансформувати і систему об'єктів бухгалтерського обліку, забезпечивши їх структуризацію за векторами діяльності та виходячи з галузевих особливостей діяльності у сфрері ЖКГ. Тому завданням організації бухгалтерського обліку $є$ обґрунтування такої структури та рівнів аналітики, які б дали змогу отримувати інформацію про матеріально-ресурсне та кадрове забезпечення окремих бізнес-процесів та підпроцесів.

Тож дослідимо сутність, види та особливості бізнес-процесів компаній. В. Стаднік та П. Іжевський визначають бізнес-процес як «сукупність логічно взаємопов'язаних завдань (ланцюжок робіт, операцій, функцій) зі створення споживчої цінності для зацікавлених у ній осіб (груп), що виконуються в межах певної організаційної оболонки, спроєктованої за критеріями максимальної вигоди від поєднання унікальних можливостей учасників ланцюжка створення цінності» [5]. Виділяючи у цьому визначенні саме функціональний та операційний аспекти, зауважимо, що об'єкти бухгалтерського обліку, які виникають за операціями, слід класифікувати на основі структурування самих господарських операцій керуючої компанії. Пропонуємо таку структуру бізнес-процесів досліджуваних компаній (рис. 1).

Передусім слід визначити бізнес-процес «Підтримка фрункціонування та розвитку матеріально-технічної бази». На цьому етапі основними об'єктами бухгалтерського обліку будуть об'єкти основних засобів та інших необоротних матеріальних активів, а також капітальні інвестиції та витрати операційної діяльності, пов'язані $з$ операціями і процедурами підтримки матеріально-технічної бази. Продемонстроване структурування бізнес-процесів дасть змогу виокремлювати капітальні інвестиції та витрати на підтримку фрункціонування і розвиток матеріально-технічної бази, зокрема аналітичний облік витрат на підтримку окремих об'єктів основних засобів чи їх комплексів дасть змогу встановити об'єкти виникнення витрат та калькулювати собівартість окремих видів сервісно-технічних послуг.

Окремо слід виділити бізнес-процес «Підтримка функціонування та розвитку онлайнплатформи", адже її використання вимагає не тільки виокремлених технічно-комп'ютерних 


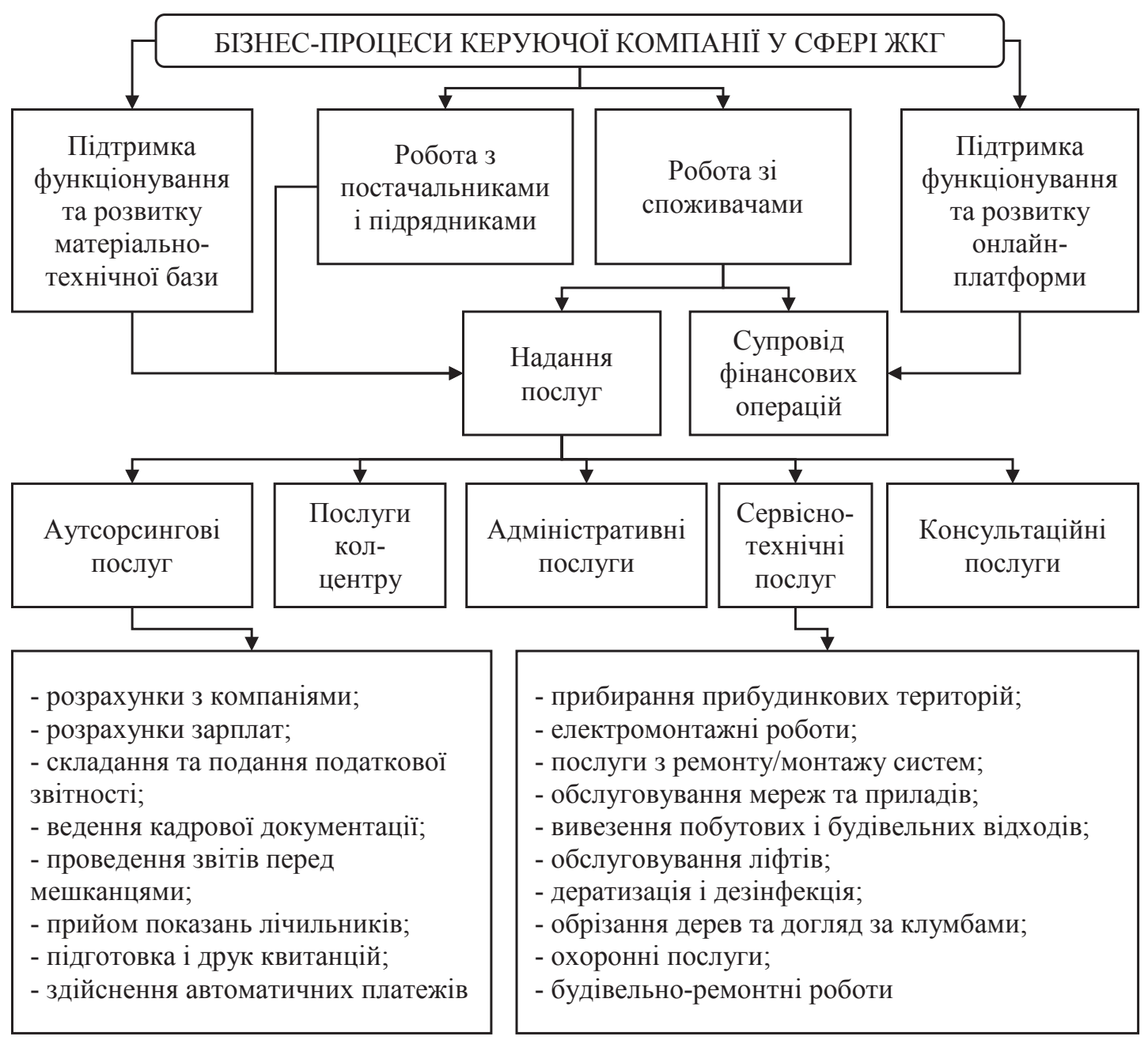

Рис. 1. Бізнес-процеси діяльності керуючої компанії у сфері ЖКГ

Джерело: складено автором

комплексів, здатних протистояти кіберзагрозам, та достатньо містких серверів для накопичення всього масиву даних про взаємодію компанії зі споживачами. Цей бізнеспроцес вимагає розроблення власного або використання ліцензованого програмного забезпечення, формування баз даних, тому в обліку слід структурувати об'єкти нематеріальних активів та виокремити операції 3 ними, адже використання спеціалізованих програмних продуктів та платфрорм хмарних сервісів провокуватиме значну суму витрат керуючої компанії, які слід контролювати та встановлювати напрями оптимізації. Тут виникають пов'язані із цим витрати на дослідження та розроблення, витрати капітального характеру на модернізацію онлайн-платфрорми, а також витрати на інфрормаційну та комп'ютерну підтримку й обслуговування ії̈ роботи.

Використання платформ для взаємодії зі споживачами дає змогу акумулювати масиви даних, які потенційно можуть становити активи керуючої компанії, адже в умовах розвитку аналітики на основі Big Data знеособлені масиви даних можуть містити інформацію, яка потенційно монетизується в умовах цифровізації економіки.

Окремого підходу вимагають процеси роботи з постачальниками і підрядниками, адже вони $€$ реальними постачальниками послуг, надання яких населенню адмініструє керуюча компанія. Бізнес-процес «Робота 3 постачальниками і підрядниками» охоплює договірну роботу та операції придбання товарів та послуг, їх відповідне фрінансове обслуговування, а також операції нарахування пов'язаних із цим податків та зборів. За постачальниками і підрядниками слід виділяти активи та послуги, які придбає у них керуюча компанія, а також обсяги наданих житловокомунальних послуг, які сама керуюча компанія не надає.

Складнішим є бізнес-процес «Робота зі споживачами", адже він охоплює не тільки надання послуг, зокрема аутсорсингових (наприклад, 
бухгалтерських), сервісно-технічних (прибирання, ремонту та монтажу, обслуговування мереж та ліфтів, вивезення побутових і будівельних відходів, дезинфекція, обрізка дерев та догляд за клумбами, охорона тощо), адміністративних (видача довідок і т. ін.), консультаційних послуг (надання технічних, юридичних, організаційних консультацій) та послуг колцентру, а й матеріально-технічне, ресурсне, кадрове забезпечення їх надання.

Виокремлення кожного виду послуг дає змогу конкретизувати об'єкти калькулювання їхньої собівартості та диференціювати методику калькулювання. Окрім того, витрати ресурсів по них також будуть різними, вимагатимуть або не вимагатимуть залучення підрядників тощо. Це прямо впливає на організацію та методику бухгалтерського обліку операцій керуючої компанії у сорері ЖКГ під час її роботи зі споживачами.

Зокрема, за такими операціями об'єктами будуть майно та ресурси керуючої компанії, інші витрати на надання послуг, доходи від їх надання, а також розрахунки з працівниками, суми податкових зобов'язань, які нараховуються за операціями надання послуг. До цього процесу також належить супровід фрінансових операцій, що означає потребу належного обліку дебіторської заборгованості з відповідними резервами сумнівних боргів, здійснення грошових розрахунків, урахування субсидій та пільг.

Базуючись на цілях управління бізнеспроцесами, обґрунтованих О.В. Ольшанським [3], уважаємо за доцільне встановити цілі організації бухгалтерського обліку в частині розроблення та впорядкування об'єктів бухгалтерського обліку керуючої компанії у сорері ЖКГ:

1) розроблення структури рахунків аналітичного обліку роботи матеріально-технічної бази та обладнання відповідно до структури ресурсів, які споживаються в межах кожного бізнеспроцесу (з можливістю ідентифікації нормативних показників їх використання);

2) встановлення деталізованої номенклатури переліку операцій та видів робіт, які виконуються персоналом за кожним бізнес-процесом, і для визначення резервів підвищення продуктивності праці виходячи з обсягів виконаних робіт та конкретних процедур;

3) розроблення структури рахунків аналітичного обліку розрахунків зі споживачами з можливістю встановлення індивідуального обсягу спожитих послуг та в межах кожного підпроцесу (з можливістю ідентифрікації нормальних показників їх використання, скорочення чи розширення споживання);
4) оптимізація системи управління бізнеспроцесами на основі вдосконалення інорормаційної підтримки процесу комунікації між рівнями управління бізнес-процесами.

Використання обґрунтованого вище підходу до ідентифікації об'єктів бухгалтерського обліку дасть змогу належно організовувати та вести бухгалтерський облік господарських операції керуючої компанії з надання послуг у сорері ЖКГ належним чином. Це сприятиме зростанню ефективності використання ресурсів як самої компанії, так і споживачів, підвищенню прозорості інфрормації для управління кожним бізнес-процесом та інформування споживачів й оприлюднення, оперативному використанню інфрормації із загальнодержавних реєстрів відкритих даних, формуванню інфрормаційного базису та аналітичного інструментарію ухвалення управлінських рішень.

Висновки 3 проведеного дослідження. Упровадження обґрунтованої вище системи об'єктів бухгалтерського обліку дасть змогу в подальшому організовувати та вести бухгалтерський облік господарських операцій керуючої компанії у сорері ЖКГ належним чином, що сприятиме:

1) зростанню едективності використання ресурсів як самої компанії, так і споживачів та ОСББ, що дає змогу досягати економії, реінвестувати заощаджені кошти у модернізацію матеріально-технічної бази та бізнес-процесів компанії;

2) підвищенню прозорості інформації, яка формується у системі бухгалтерського обліку, на основі впровадження системи аналітичного обліку виходячи з особливостей об'єкта бухгалтерського обліку та бізнес-процесу, до якого він відноситься, адже управління кожним бізнес-процесом формує запит до інформаційної системи підприємства, визначаючи контекст та індикатори вихідної облікової інформації, на основі якої буде ухвалюватися управлінське рішення;

3) оперативному використанню інформації із загальнодержавних реєстрів відкритих даних, адже конкретизація об'єкту бухгалтерського обліку визначатиме можливість інтеграції інформації щодо нього у бухгалтерському обліку з відповідними даними державних реєстрів у режимі реального часу (сучасні інформаційні платформи дають змогу це робити);

4) формуванню інформаційно-аналітичного базису управління бізнес-процесами керуючої компанії на основі оперативної та аналітичної інфрормації, яка створюватиметься в єдиному інорормаційному просторі, безпечному завдяки використанню хмарних сервісів та інструментів кібер-захисту. 


\section{Список використаних джерел:}

1. Дерій В.А., Гуменна-Дерій М.В. Управлінський облік і аналіз бізнес-процесів у підприємстві. Проблеми теоріїта методологіїбухгалтерського обліку, контролю іаналізу. 2018. № 2(40). С. $12-18$.

2. Криворучко О.М. Інтегрований підхід до удосконалення бізнес-процесів підприємства. Економіка транспортного комплексу. 2018. № 32. С. 17-29.

3. Ольшанський О.В. Розробка концепції удосконалення управління бізнес-процесами підприємств торгівлі. Бізнес-навігатор. 2018. № 6(49). С. 110-113.

4. Ольшанський О.В., Ключарьов В.М. Теоретико-методологічні аспекти управління бізнес-процесами підприємств торгівлі. Науковий погляд: економіка та управління. 2019. № 1(63). С. $130-136$.

5. СтадникВ., ІжевськийП. Бізнес-системи та бізнес-процеси сучаснихпідприємств: взаємозв'язок взаємозалежність структур та ефективності. Соціально-економічні проблеми і держава. 2018. № 1(18). С. 137-148.

6. Стец І.І. Ідентифрікація бізнес-процесів підприємства. Інфбраструктура ринку. 2019. Вип. 33. С. 233-240.

7. Таранюк Л.М. Методологія реінжинірингу бізнес-процесів промислових підприємств. Механізм регулювання економіки. 2011. № 1. С. 111-119.

8. Чернобай Л.І., Дума О.І. Бізнес-процеси підприємства: класифікація та структурно-ієрархічна модель. Економічний аналіз. 2015. № 2. С. 171-182.

\section{References:}

1. Derii V. A., \& Humenna-Derii M. V. (2018) Upravlinskyi oblik i analiz biznes-protsesiv u pidpryiemstvi [Management accounting and analysis of business processes in the enterprise]. Problemy teorii ta metodolohii bukhhalterskoho obliku, kontroliu i analizu (electronic journal), no. 2(40), pp. 12-18.

2. Kryvoruchko O. M. (2018) Intehrovanyi pidkhid do udoskonalennia biznes-protsesiv pidpryiemstva [An integrated approach to improving the enterprise's business processes]. Ekonomika transportnoho kompleksu (electronic journal), no. 32, pp. 17-29.

3. Olshanskyi O. V. (2018) Rozrobka kontseptsii udoskonalennia upravlinnia biznes-protsesamy pidpryiemstv torhivli [Development of the concept of improving the management of business processes of trade enterprises]. BIZNES-NAVIHATOR (electronic journal), no. 6(49), pp. 110-113.

4. Olshanskyi O. V., \& Kliucharov V. M. (2019) Teoretyko-metodolohichni aspekty upravlinnia biznes-protsesamy pidpryiemstv torhivli [Theoretical and methodological aspects of managing business processes of trade enterprises]. Naukovyi pohliad: ekonomika ta upravlinnia (electronic journal), no. 1(63), pp. 130-136.

5. Stadnyk V., Izhevskyi P. (2018) Biznes-systemy ta biznes-protsesy suchasnykh pidpryiemstv: vzaiemozviazok vzaiemozalezhnist struktur ta efektyvnosti [Business systems and business processes of modern enterprises: the interrelation of interdependence of structures and efficiency]. Sotsialno-ekonomichni problemy i derzhava (electronic journal), no. 1(18), pp. 137-148.

6. Stets I. I. (2019) Identyfikatsiia biznes-protsesiv pidpryiemstva [Identification of business processes of the enterprise]. Infrastruktura rynku (electronic journal), no. 33, pp. 233-240.

7. Taraniuk L. M. (2011) Metodolohiia reinzhynirynhu biznes-protsesiv promyslovykh pidpryiemstv [Methodology of reengineering business processes of industrial enterprises]. Mekhanizm rehuliuvannia ekonomiky (electronic journal), no. 1, pp. 111-119.

8. Chernobai L. I., Duma O. I. (2015) Biznes-protsesy pidpryiemstva: klasyfikatsiia ta strukturno-iierarkhichna model [Business processes of the enterprise: classification and structural-hierarchical model]. Ekonomichnyi analiz (electronic journal), no. 2, pp. 171-182. 